\title{
Failure of the ammonia oxidation process in two pharmaceutical wastewater treatment plants is linked to shifts in the bacterial communities
}

\author{
L. Wittebolle ${ }^{1}$, N. Boon ${ }^{1}$, B. Vanparys ${ }^{2}$, K. Heylen ${ }^{2}$, P. De Vos ${ }^{2}$ and W. Verstraete ${ }^{1}$ \\ ${ }^{1}$ Laboratory of Microbial Ecology and Technology (LabMET), and ${ }^{2}$ Laboratory of Microbiology, Ghent University, Ghent, Belgium
}

2005/0335: received 1 April 2005, revised 23 June 2005 and accepted 25 June 2005

\begin{abstract}
L. Wittebolle, N. BOON, B. VAnparys, K. heylen, P. DE VOS AND W. Verstraete. 2005.
\end{abstract}

Aims: To investigate whether two different wastewater treatment plants (WWTPs) - treating the same pharmaceutical influent - select for a different bacterial and/or ammonia oxidizing bacterial (AOB) community. Methods and Results: Molecular fingerprinting demonstrated that each WWTP had its own total bacterial and AOB community structure, but Nitrosomonas eutropha and N. europea were dominant in both WWTP A and B. The DNA and RNA analysis of the AOB communities revealed different patterns; so the most abundant species may not necessarily be the most active ones. Nitritation failures, monitored by chemical parameter analysis, were reflected as AOB community shifts and visualized by denaturing gradient gel electrophoresis (DGGE)-based moving window analysis.

Conclusions: This research demonstrated the link between functional performance (nitritation parameters) and the presence and activity of a specific microbial ecology (AOB). Clustering and moving window analysis based on DGGE showed to be valuable to monitor community shifts in both WWTPs.

Significance and Impact of the Study: This study of specific community shifts together with functional parameter analysis has potential as a tool for relating functional instability (such as operational failures) to specificbacterial community shifts.

Keywords: ammonia oxidizing bacteria, clustering, denaturing gradient gel electrophoresis, moving window analysis, nitritation, nucleotide sequence, residual $\mathrm{NH}_{4}{ }^{+}-\mathrm{N}$.

\section{INTRODUCTION}

In wastewater treatment plants (WWTPs), incoming ammonium is converted to nitrite (nitritation) by a defined subgroup of bacteria, i.e. the ammonia-oxidizing bacteria (AOB). This nitrite can consequently be oxidized to nitrate by the nitrite-oxidizing bacteria (NOB) (nitratation). The successive combination of both reactions is called nitrification (Focht and Verstraete 1977). Malfunctioning of nitrification can cause serious ecological risks (eutrophication and foam formation) and related health problems (fish death,

Correspondence to: Willy Verstraete, Laboratory of Microbial Ecology and Technology (LabMET), Ghent University, Coupure Links 653, B-9000 Ghent,

Belgium (email: milly.verstraete@ugent.be). toxic nitrite and/or nitrate in drinking water and methaemoglobinaemia) (Vedel et al. 1998; Huertas et al. 2002; Philips et al. 2002; Jensen 2003; Das et al. 2004).

The community composition of the functional bacterial groups active in WWTPs can be assessed by denaturinggradient gel electrophoresis (DGGE) analysis of $16 \mathrm{~S}$ rRNA (Wagner et al. 1993; Blackall et al. 1998; Liu et al. 1998). DGGE is a molecular technique that allows the separation of DNA fragments of the same length (up to $500 \mathrm{bp}$ ) (Myers et al. 1985), but with different base-pair sequences. It was introduced into environmental microbiology to determine the genetic diversity of complex microbial populations (Muyzer et al. 1993). Ever since, it has been shown to be useful for studying the bacterial communities in a variety of 
environmental samples, e.g. soil (Seghers et al. 2003), plants (Seghers et al. 2004), water (Teske et al. 1996) and activated sludge (Boon et al. 2000). This molecular technique is also useful for studying population dynamics and stress responses (Amann et al. 1998; Head et al. 1998; Torsvik et al. 1998; Ogram 2000). Hence, DGGE analysis can be regarded as an elegant tool to investigate microbial populations or bacterial subpopulations when using group specific primers for the PCR reaction preceding the DGGE profiling. Possible shifts in these communities can further be analysed by clustering and moving window analysis (Possemiers et al. 2004). The 16S rRNA gene pool diversity is typically the basis for analysis of the microbial community. The sample concentration of DNA is not directly linked with cell activity, because DNA is relatively stable. As a result, DNA-based fingerprints reveal the community structure of the most abundant bacteria, however, without differentiating on basis of their activity. On the contrary, with rRNA-based fingerprints the most active microorganisms can be studied, because nonactive cells will have limited rRNA amounts to be transcribed into cDNA (Amann et al. 1995).

During a survey of 6 months, DGGE was used to molecularly monitor the bacterial and specifically the AOB communities in the activated sludge of a pharmaceutical plant. Two WWTP types present on the site and operating on the same industrial wastewater were studied. We investigated whether shifts in nitrification performance were reflected in the total bacterial and/or the AOB communities of both WWTPs. Furthermore, a comparison between DNA and RNA based DGGE analysis was performed to examine the most appropriate method for studying WWTP disturbances.

\section{MATERIALS AND METHODS}

\section{Experimental setup and sampling}

Approximately every 2 weeks during 148 consecutive days from 9 July 2003 to 3 December 2003, sampling was carried out in two different types of WWTPs treating the same influent of a pharmaceutical production company in Belgium. The first type (WWTP A) was a conventional WWTP with a completely mixed aeration tank (where nitrification occurs) (Limpiyakorn et al. 2004). The second type (WWTP B) was identical to the first type, but with an additional, preceding basin in which ammonification was allowed to occur. Sampling took place from the beginning of July 2003 when WWTP A was started up after a period of nonfunctioning and WWTP B was started up with sludge from WWTP A. At the sampling site, the sludge was subjected to a paraformaldehyde fixation and frozen at $-20^{\circ} \mathrm{C}$ to preserve the nucleotides of the microbial community (Zarda et al. 1997). Upon arrival at the laboratory, all samples were subjected to DNA and RNA extraction.

\section{Nitrification parameter analysis}

The nitrite, nitrate and ammonium content of the effluent was analysed by ion chromatography after a 10-min centrifugation at $5000 \mathrm{~g}$ and filtering through a $0.45 \mu \mathrm{m}$ filter. A DX-600 system (Dionex, Wommelgem, Belgium) was used which consisted of a Dionex AS50 autosampler (with an injection volume of $100 \mu \mathrm{l}$ ), a Dionex GP50 pump and a Dionex ED50 electrochemical detector. Data analysis was performed with the PeakNet 6 software system version 6.10 (Dionex, Wommelgem, Belgium). The Ionpac columns AS9-HC $(250 \times 4 \mathrm{~mm}$ ID, $9-\mu \mathrm{m}$ particle size; Dionex $)$ and CS12-HC $(250 \times 4 \mathrm{~mm}$ ID, $8 \mu \mathrm{m}$ particle size; Dionex $)$ were used for anion and cation separation respectively. The mobile phase consisted of $\mathrm{Na}_{2} \mathrm{CO}_{3}\left(9 \mathrm{mmol} \mathrm{l} \mathrm{l}^{-1}\right)$ and methanesulfonic acid $\left(20 \mathrm{mmol} \mathrm{l}^{-1}\right)$ for anion and cation analysis respectively. The flow rate was $1 \mathrm{ml} \mathrm{min}^{-1}$. Kjeldahl nitrogen $\left(N_{\text {Kjeldahl }}\right)$ was analysed by standard methods (Greenberg et al. 1992) and the data were checked for the absence of a correlation between the nitrogen load of the system ( $N_{\text {Kjeldahl }}$ in influent) and the amount of $N_{\text {Kjeldahl }}$ in the effluent. This way, possible changes in the effluent $N_{\text {Kjeldahl }}$ could be due to failing ammonia oxidizers. The organic nitrogen $\left(N_{\text {organic }}\right)$ was calculated as the difference between the $N_{\text {Kjeldahl }}$ and the $\mathrm{NH}_{4}{ }^{+}-\mathrm{N}$.

\section{Nucleic acid extraction and PCR amplification}

Nucleic acids were extracted from the sludge samples by using a protocol previously described (Boon et al. 2000). To obtain pure DNA, a 100- $\mu$ l aliquot of each of the extracted nucleic acid samples was purified with Wizard PCR preps (Promega, Madison, WI, USA) and the DNA concentration was measured spectrophotometrically at $260 \mathrm{~nm}$ (UVIKON 932; Kontron Instruments, Milan, Italy). To obtain rRNA, samples were treated as described previously (Boon et al. 2003). A reverse-transcriptase reaction was used to convert all rRNA into cDNA (Boon et al. 2003).

To obtain DNA and cDNA amplicons for further analysis of the total bacterial community by DGGE, a single round PCR was performed with primers targeting all bacteria (P388f and P518r) (Øvreås et al. 1997). To study the AOB community a nested PCR approach was used (Boon et al. 2002). The first round made use of the primers CTO189AB, CTO189C and CTO653r to amplify specifically the AOB (Kowalchuk et al. 1997). The second round was performed with the total bacterial primers. All PCRs were performed with a Biozym thermal cycler (Biozym; Hess., Oldendorf, Germany). The PCR master mix contained the following 
components: $10 \mathrm{X}$ reaction buffer with $15 \mathrm{mmol}^{-1} \mathrm{MgCl}_{2}$, $200 \mu \mathrm{mol} \mathrm{l}^{-1}$ of each deoxynucleoside triphosphate, $0 \cdot 2 \mu \mathrm{mol} \mathrm{l}^{-1}$ of each primer, $2.5 \mathrm{U}(100 \mu \mathrm{l})^{-1}$ of Taq DNA polymerase (Promega), $400 \mathrm{ng} \mu \mathrm{l}^{-1}$ of bovine serum albumin (Hoffman-La Roche, Basel, Switzerland), and DNase- and RNase-free filter-sterilized water (Sigma-Aldrich Chemie, Steinheim, Germany). In both the single round PCR and the first PCR round of the nested approach, $1 \mu \mathrm{l}$ of purified DNA was added to $24 \mu \mathrm{l}$ of the PCR master mixture. In the second round of the nested approach, $1 \mu \mathrm{l}$ of amplified product from the first round was added to $24 \mu \mathrm{l}$ of new PCR master mix. After each PCR, the size of the amplicon was verified by running it next to a low range DNA Massruler ${ }^{\mathrm{TM}}$ (Fermentas, Burlington, ON, Canada) on a $1 \%$ agarose gel.

\section{DGGE analysis}

A Bio-Rad DGene ${ }^{\text {TM }}$ system (Hercules, CA, USA) was used to perform DGGE analysis as described previously (Boon et al. 2002). In brief, PCR amplification samples were loaded onto $8 \%(\mathrm{w} / \mathrm{v})$ polyacrylamide gels in $1 \mathrm{X}$ TAE $\left(20 \mathrm{mmol}^{-1}\right.$ Tris, $10 \mathrm{mmol} \mathrm{l}^{-1}$ acetate, $0.5 \mathrm{mmol} \mathrm{l}^{-1}$ EDTA; pH 7·4). The polyacrylamide gels were made with a denaturing gradient ranging from $45 \%$ to $60 \%$ (100\% denaturing contains $7 \mathrm{~mol} \mathrm{l}^{-1}$ urea and $40 \%$ formamide). Overnight electrophoresis was performed for $16 \mathrm{~h}$ at $60^{\circ} \mathrm{C}$ and $38 \mathrm{~V}$ and subsequently the gels were soaked for $20 \mathrm{~min}$ in $200 \mu \mathrm{l} 1 \mathrm{X}$ TAE supplemented with $17 \mu \mathrm{l}$ SYBR Green I nucleic acid gel stain (dilution, 1 : 10 000; FMC BioProducts, Rockland, ME, USA). Afterwards, images of the gels were taken with a UV transillumination table combined with a video camera module (Vilbert Lourmat, Marne-la Vallé, France).

\section{Analysis of DGGE patterns}

The obtained DGGE patterns were subsequently analysed using Bionumerics software version 2.0 (Applied Maths, Sint-Martens-Latem, Belgium). This software comprises defining the different lanes, background subtraction, marker assisted normalization, which includes compensating for intensity differences between the lanes, and assigning the different bands in each lane. A matrix of similarities for the densiometric curves of the band patterns was calculated based on the Pearson product-moment correlation coefficient and dendrograms were created by using UPGMA linkage. Relevant and nonrelevant clusters were further separated by the cluster cut-off method (Bionumerics Manual 2.5; Applied Maths, Sint-Martens-Latern, Belgium). The moving window analysis consisted of plotting the evolution in time of the correlation values between two consecutive analysing dates and is helpful when evaluating bacterial community stabilities (Possemiers et al. 2004).
For sequence analysis purposes, the desired DGGE band fragments were cut out and cloned with the pCR ${ }^{\circledR} 2.1-$ TOPO $^{\circledR}$ cloning kit (Invitrogen, Carlsbad, CA, USA) according to the manual instructions. DNA sequencing was carried out by IIT Biotech-Bioservice (Bielefeld, Germany). DNA sequence analysis was performed using the BLAST server of the National Centre for Biotechnology Information (http://www.ncbi.nlm.nih.gov) with the BLAST algorithm and specifically with the BLASTN program. Sequences were deposited in the GenBank database and were assigned NCBI accession numbers AY968066-AY968072.

\section{RESULTS}

\section{Evaluation of the nitrification efficiency}

During a period of $c .5$ months nitrification was monitored in two pharmaceutical WWTPs treating the same influent. Table 1 represents an overview of the nitrification parameters that were measured with periods of poor nitritation performance indicated in grey. This was based on effluent concentrations of ammonium-nitrogen $>2 \mathrm{mg} \mathrm{N} \mathrm{l}^{-1}$. Almost all the nitrogen in the influent is present as recalcitrant nitrogen (Table 1), indicating the importance of the ammonification process. WWTP A experienced a poor nitritation around day 1 (because of the start-up of the WWTP), around day 64 , and from day 120 to 148 . WWTP $\mathrm{B}$ had poor nitritation from day 64 to 78 , and from day 134 to 148 . Overall, the most important nitrogen differences between both WWTPs were noticed around day 78 and 120 .

\section{Total bacterial DGGE analysis}

The results of the cluster analysis of the DNA based DGGE gel revealed that each WWTP had a distinct bacterial community. The separate clustering of the day 1 sample of WWTP B was because of the start-up of it (Fig. 1). Furthermore, for each WWTP type, smaller clusters although not separated by the statistical cluster cut-off method - indicated smaller community shifts over time. Over time, the bacterial community of WWTP A shifted between day 8 and 15, day 28 and 43, and day 64 and 78. In the case of WWTP B shifts occurred between day 28 and 43, and day 64 and 78. For both WWTP types the shift around day 64 was the most significant one (Fig. 1). This day 64 shift was also clearly noted in the moving window analysis based on the DGGE profiles obtained after PCR amplification with total bacterial primers (Fig. 4a). Curves for both WWTP types followed a similar trend starting with a high correlation coefficient that decreased towards a day 64 low point after which both curves increased again. Furthermore, it was noted that this final increase was higher for WWTP B 


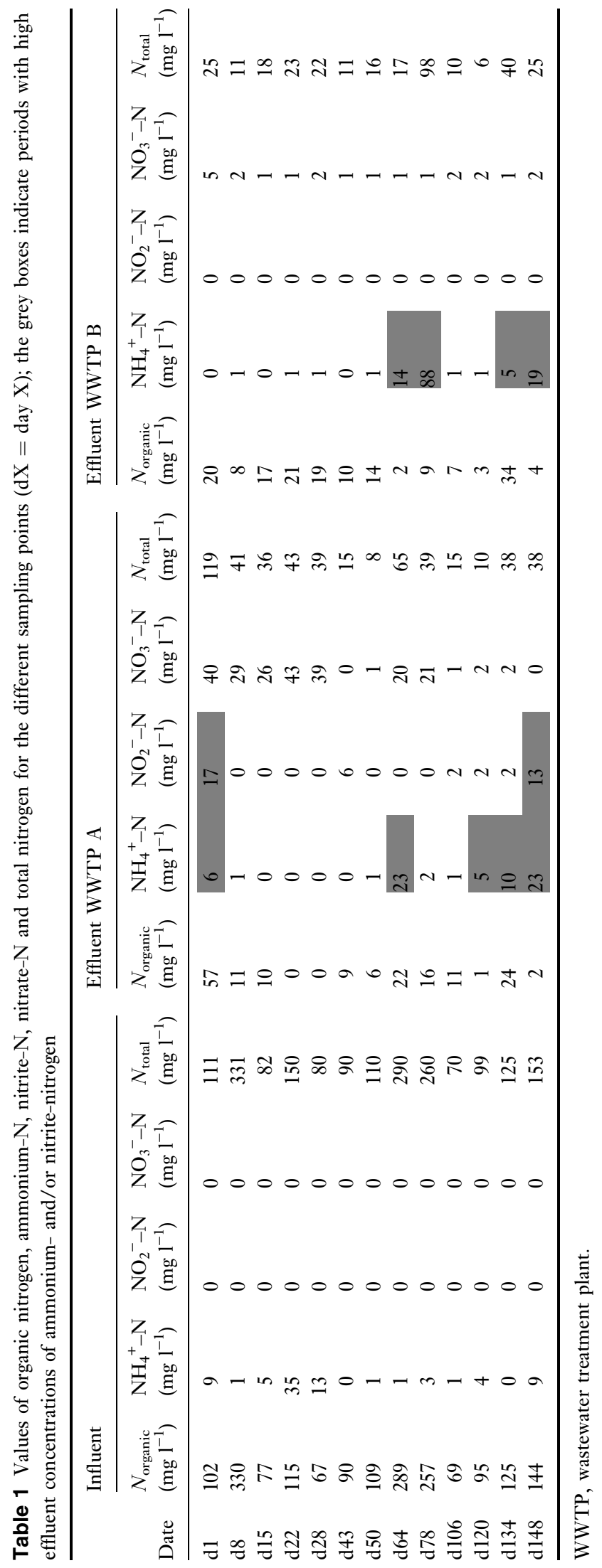

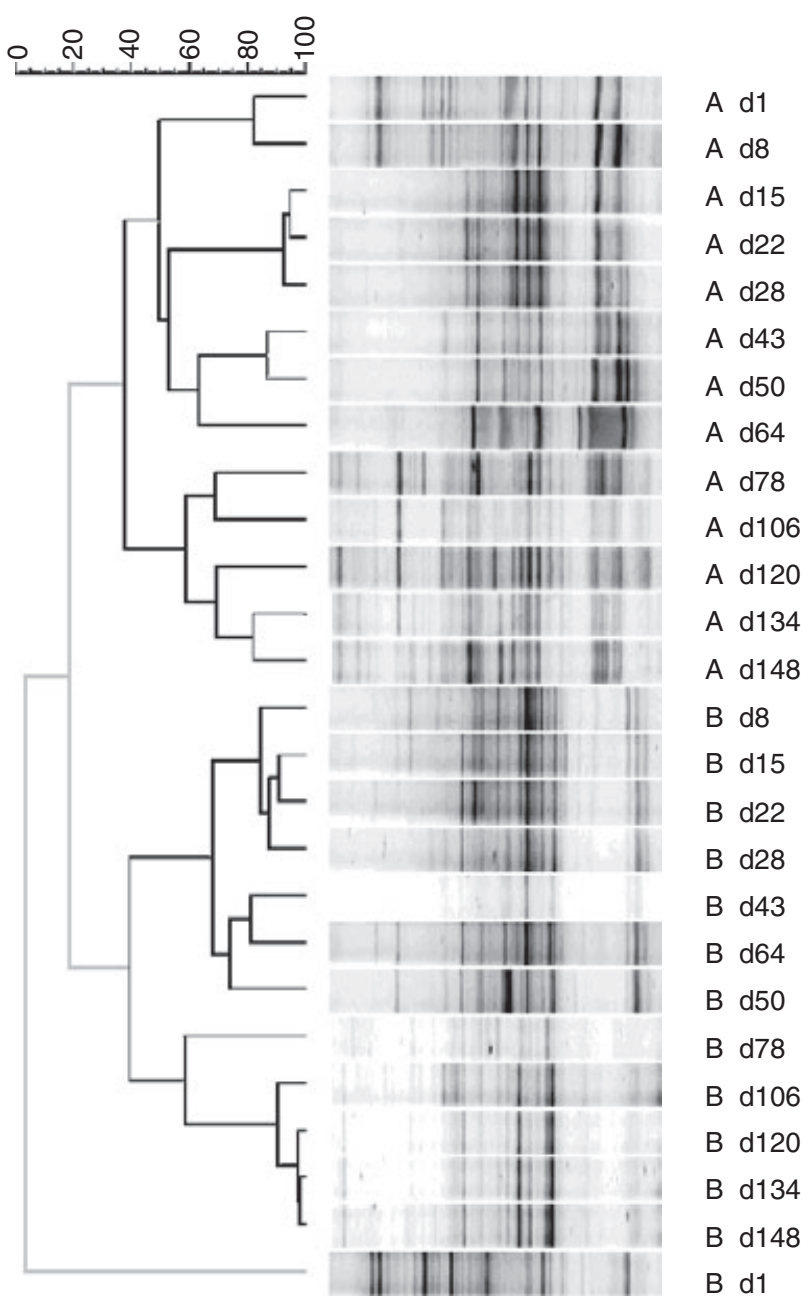

Fig. 1 Cluster analysis of the denaturing gradient gel electrophoresis pattern for the total bacterial community on DNA basis of wastewater treatment plants (WWTP) A and B, sampled at different dates $(\mathrm{dX}=$ day $\mathrm{X})$. Note the clear-cut separation of both WWTPs. Relevant (black lines) and nonrelevant (grey lines) clusters were separated by the cluster cut-off method

than for WWTP A, which also fluctuated more in the period before day 64 . The low correlation coefficient for WWTP B in the beginning of the curve was because of start-up reasons.

Besides the DNA based DGGE, a rRNA based DGGE was performed to compare the active total bacterial communities in both WWTPs. Both rRNA based DGGE patterns clustered in the same way as their respective DNA based DGGEs did (data not shown).

\section{DGGE analysis of the ammonia oxidizing bacteria}

Similar to the analysis of the bacterial community, a DGGE analysis was performed on the ammonia-oxidizing bacterial 


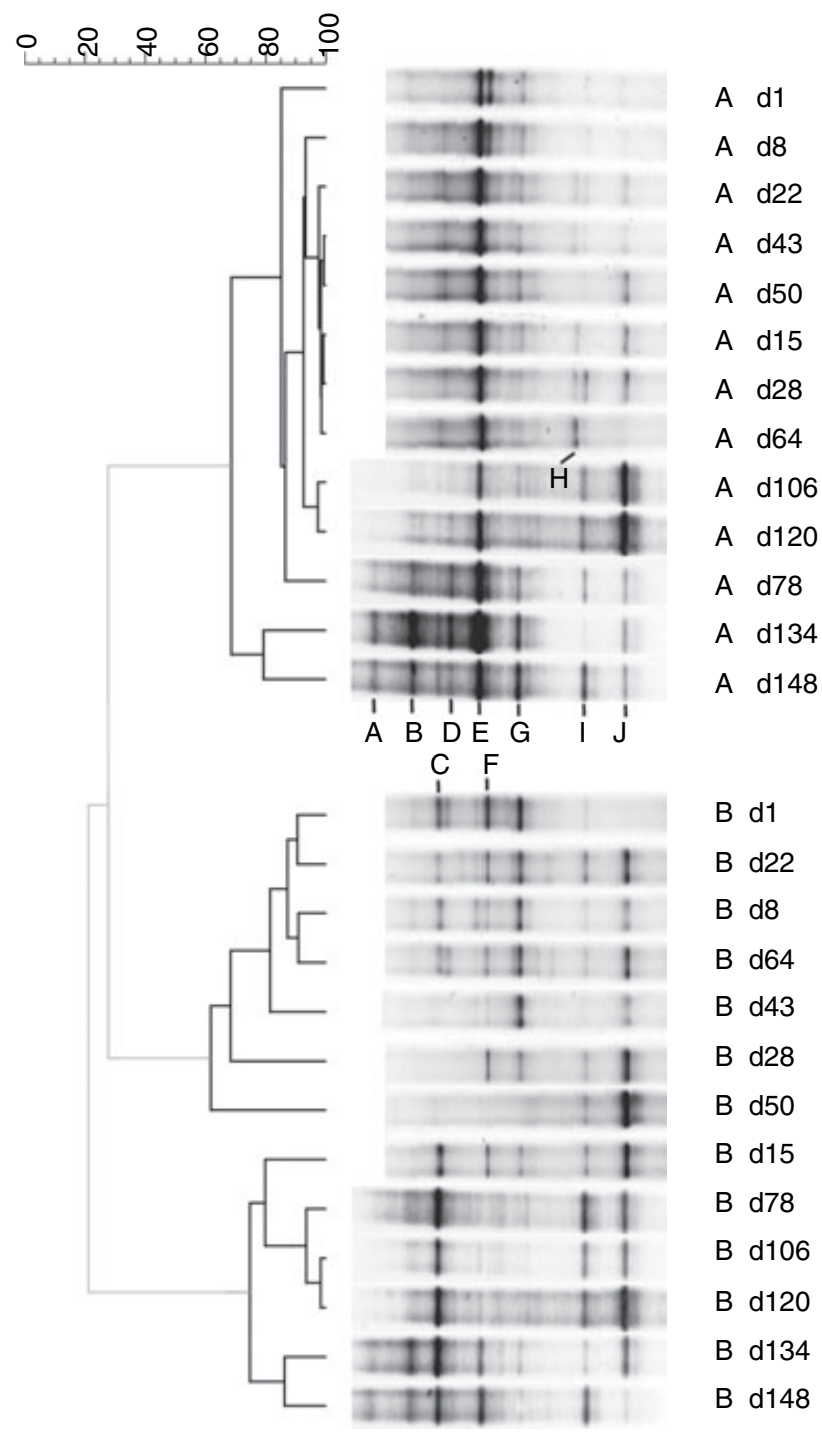

Fig. 2 Denaturing gradient gel electrophoresis pattern of the ammonia oxidizing bacteria on basis of DNA analysis of wastewater treatment plants $\mathrm{A}$ and $\mathrm{B}$, sampled at different dates $(\mathrm{dX}=$ day $\mathrm{X})$. Relevant (black lines) and nonrelevant (grey lines) clusters were separated by the cluster cut-off method

community (AOB). A comparison was made between the numerically most abundant AOBs (DNA) and the most active AOBs (RNA) present in the samples.

For WWTP A, differences in presence and dominance of the bands between DNA and RNA based DGGE patterns were observed. In total more than 10 different bands were visible, although a number of bands were quite weak. The 10 most dominant bands of the DGGE pattern (designated A till $\mathrm{J}$ in Figs 2 and 3) were partially sequenced. Band C revealed 97\% similarity with Nitrosomonas europaea ATCC 19718 (BX321856), band E 100\% similarity with the

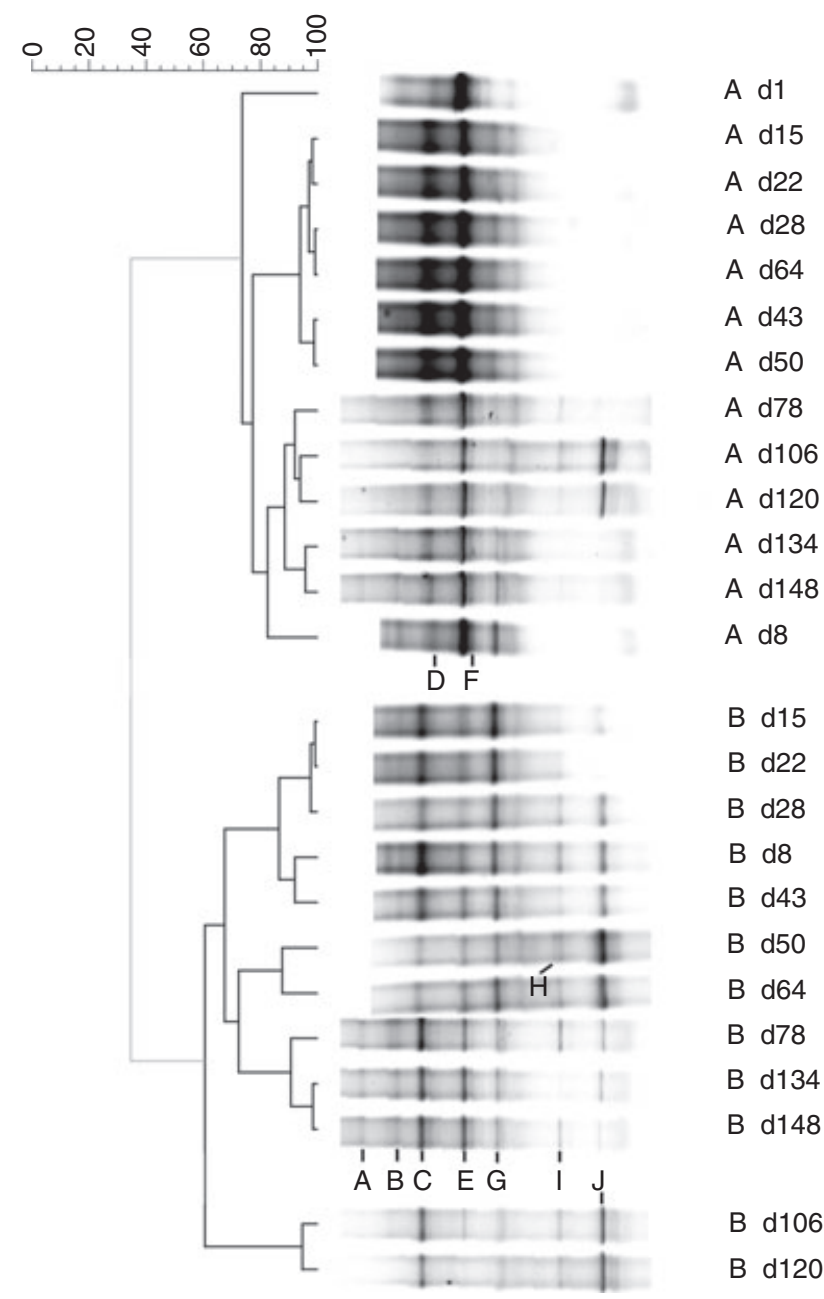

Fig. 3 Denaturing gradient gel electrophoresis pattern of the ammonia oxidizing bacteria on basis of RNA analysis of wastewater treatment plants (WWTP) A and B, sampled at different dates ( $\mathrm{dX}=$ day $\mathrm{X})$. Relevant (black lines) and nonrelevant (grey lines) clusters were separated by the cluster cut-off method. Note the absence of the day 1 sample of WWTP B as this gave no amplification product

Nitrosomonas eutropha isolate $\mathrm{Nm} 57^{\mathrm{T}}$ (AJ298739), band $\mathrm{F}$ $96 \%$ similarity with Nitrosomonas oligotropha isolate $\mathrm{Nm} 45^{\mathrm{T}}$ (AJ298736), and band G 100\% similarity with $N$. europaea ATCC 19718 (BX321856). Although the clonation procedure was repeated several times, no clones bearing the correct sequence were obtained for bands A, B, D and H. Both bands I and J gave 97\% similarity with the DGGE found uncultured beta-Proteobacterium band CJ2-b4WWout (AY583658) and 97\% similarity with Aquaspirillum serpens (AB074518). Therefore, they can be considered as a result of CTO primer nonspecificity and were excluded from further statistical analysis (both clustering and moving window analysis) and from the discussion about the AOB analysis. 
(a)
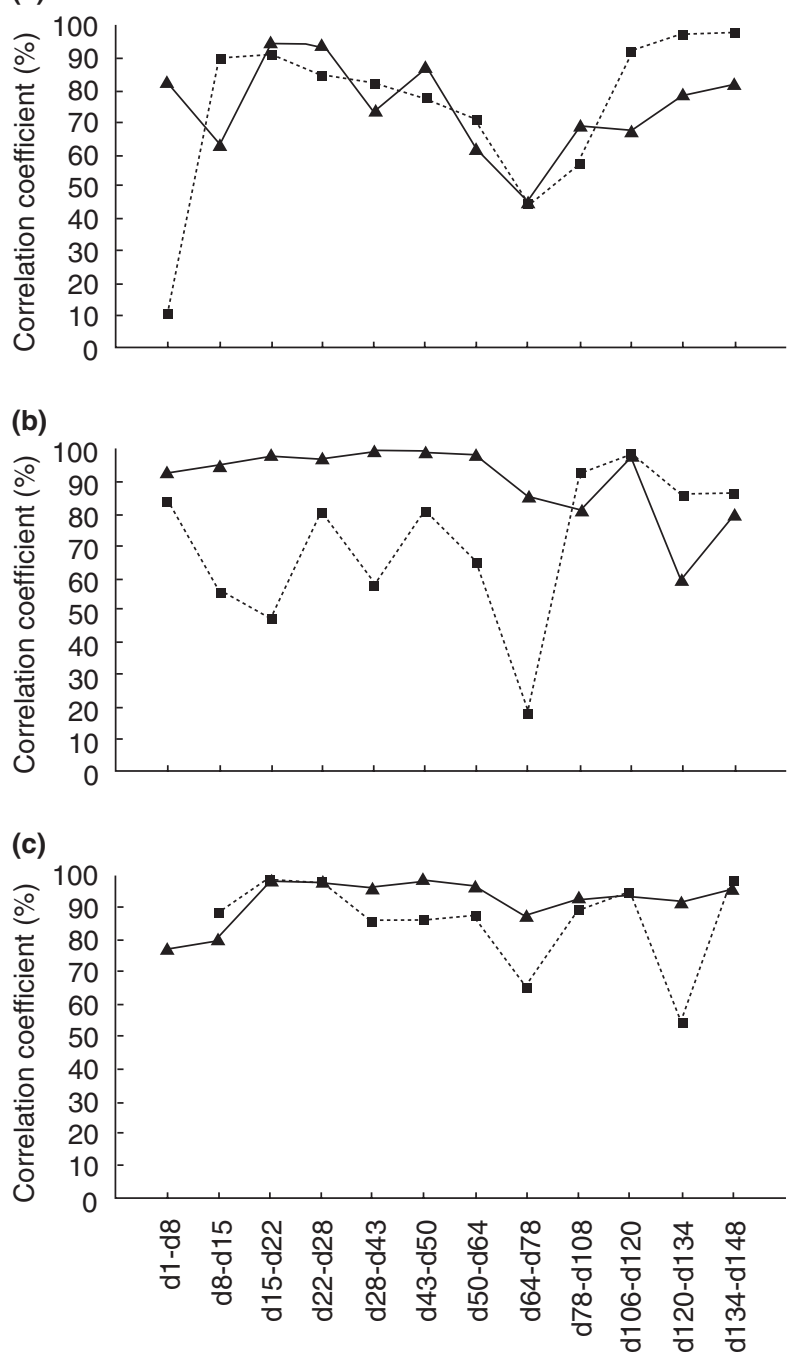

Times (Comparision of two dates)

Fig. 4 Moving window correlation on the DNA level of the total bacteria (a), and on the DNA (b) and RNA (c) level of the ammonia oxidizing bacteria communities. Each time both wastewater treatment plants (WWTP) A (full line) and WWTP B (dashed line) curves are depicted. The variability between two consecutive dates $(\mathrm{dX}=$ day $\mathrm{X})$ was calculated based on the denaturing gradient gel electrophoresis patterns as represented in Figs 1-3

The DNA based AOB DGGE pattern of WWTP A hardly changed during the first 3 months. Only one AOB ribotype (band $\mathrm{E}$ ) dominated and one other $\mathrm{AOB}$ band was clearly present (band G; as bands I and J were not AOBs). The DNA based AOB DGGE analysis of WWTP B depicted a different situation (Fig. 2). It revealed the presence of three dominant AOBs $(\mathrm{C}, \mathrm{F}$ and $\mathrm{G})$ during the first 2 months. With time, the number of different AOBs increased. From day 78 on, the ammonia-oxidizing community stayed more or less constant. Band C dominated the AOB population. On the last two sampling dates (days 134 and 148) the community was more dynamic with the number of different AOBs higher and the ribotype $\mathrm{E}$ becoming more dominant than before. This resulted in the domination by bands B, C and E (Fig. 2). Moving window analysis based on the DNA-DGGE profiles for the AOBs, showed that the ammonia-oxidizing bacterial communities of both WWTPs had clearly different correlation coefficient curves, but both reacted with a decrease towards day 64 (Fig. 4b). The WWTP A curve started with high and stable correlation coefficients which became more fluctuating from day 64 on. It was also noticed that the low point in this curve was situated a month later compared with the low point of the bacterial community curves (Fig. 4a). The WWTP B curve had an opposite course; it fluctuated highly before day 64 , had a very deep minimum on day 64 and turned into a more stable and high curve afterwards (Fig. 4b).

The RNA based AOB DGGE gel of WWTP A yielded a different pattern than the DNA-based AOB DGGE gel (Fig. 3). As the DNA based analysis showed the dominance of only one ribotype (band E), the RNA study demonstrated that both band $\mathrm{D}$ and $\mathrm{E}$ represented equally active ammonia-oxidizing ribotypes. Between day 106 and day 134, band $\mathrm{D}$ became temporarily less dominant, but band $\mathrm{E}$ remained predominant until the end of the sampling period. The RNA based AOB DGGE gel of WWTP B demonstrated the codominance of band $\mathrm{C}$ and $\mathrm{G}$ at the beginning of the sampling period. Band $\mathrm{C}$ remained dominant the whole time and was even the only dominant AOB ribotype between day 106 and 120 . However, band $\mathrm{G}$, exchanged its dominance with band $\mathrm{E}$ towards the end of the sampling period. Moving window analysis for the RNA based DGGE profiles of the AOB communities of both WWTPs showed different courses over time (Fig. 4c). Except for the first 2 weeks and the decrease around day 64, the WWTP A curve stayed very high, suggesting a stable community. The WWTP B curve fluctuated more and revealed a variable (up to $40 \%$ change) RNA community structure from day 64 on.

\section{DISCUSSION}

Nitrification parameters and the structure of the microbial community of two WWTPs (A and B) treating the same influent were monitored. Based on the residual $\mathrm{NH}_{4}{ }^{+}-\mathrm{N}$ data in Table 1 and except start-up values, nitritation experienced only failures (upper limit: $2 \mathrm{mg} \mathrm{NH}{ }_{4}{ }^{+}-\mathrm{N} \mathrm{l}^{-1}$ ) starting from around day 64 . These changing nitritation parameters were also reflected in community shifts of the AOBs as demonstrated by the statistical processing of the AOB DGGE fingerprints (Figs 2-4). The shifts were both detected by cluster analysis and moving window analysis based on the 
DGGE patterns. Moreover, molecular analysis tools have the benefit to identify the most important microbial species involved in the failure of the nitritation. This changing in nitritation performance was related to the production of imidazoles by the pharmaceutical company from day 64 on, and thus the confrontation of the microbial populations of the WWTPs with chemicals used in this production process, which are present in the influent. Imidazole production related products and used chlorinated and nonchlorinated solvents are well-known alternative substrates for ammonia and this way inhibit the growth of ammonia oxidizing bacteria (Rasche et al. 1990; Keener and Arp 1994; McCarty 1999). They influence ammonium monooxygenase (AMO) activity by three distinct mechanisms: (i) direct binding and interaction with AMO, (ii) interference with the supply of reductant needed for monooxygenase activity, and (iii) the oxidation of substrates to give products that are highly reactive and inactivate $\mathrm{AMO}$ and/or other enzymes (Keener and Arp 1993; McCarty 1999).

To follow up possible failures of the nitritation process, the residual $\mathrm{NH}_{4}{ }^{+}-\mathrm{N}$ in the effluent of the WWTPs was monitored. The data were checked for the absence of a correlation between the nitrogen load of the system ( $N_{\text {Kjeldahl }}$ in influent) and the amount of $N_{\text {Kjeldahl }}$ in the effluent. This way, possible changes in the effluent $N_{\text {Kjeldahl }}$ (and more in specific high amounts of residual $\mathrm{NH}_{4}{ }^{+}-\mathrm{N}$ ) may be because of failing ammonia oxidizers. The measuring of the amounts of organic nitrogen in the influent and effluent as an indication of a well performing ammonification were included, as this is a preceding step towards the nitritation (Kowalchuk and Stephen 2001) and the influent contained high organic nitrogen levels $\left(c .77-100 \%\right.$ of $N_{\text {total }}$; Table 1). This was of particular interest for this research, in view of the presence of a preceding ammonification step in WWTP B, but not in WWTP A. This preceding basin of WWTP B was incorporated to optimize the conversion of the high amounts of organic nitrogen to ammonia, which is readily accessible for the AOBs. In WWTP A this conversion to ammonia had to take place in the mixed aeration tank itself, causing a delay in the ammonia supply to the AOBs.

In the last decade there has been much interest in rRNA analysis (Amann et al. 1995) as a correlation was found between the growth rate of a bacterium and the cellular rRNA concentration (Poulsen et al. 1993). The data in this study support the hypothesis that rRNA analysis relates not only to the presence but also to the activity of bacteria. The DGGE AOB analysis of WWTP A showed that 16S rRNA based analysis can indeed reveal a different pattern of the microbial community structure than DNA-based analysis (Fig. 3 vs Fig. 2). The fact that band D is only weakly present at the DNA level (Fig. 2), but strongly present at the RNA level (Fig. 3) suggests that these bacteria are active and thus play a functionally more important role than expected from the DNA based DGGE. The results obtained for the total bacteria suggested that the differences between DNA and RNA-based analysis are less revealing. Hence, it appears that a $16 \mathrm{~S}$ rRNA-based analysis is valuable for evaluating the relative activity of the bacteria studied, particularly when focussing on subgroups of the entire bacterial community. Another strategy for evaluating the activity of the AOB community could have been based on the use of primers targeting the functional gene involved in the nitritation; the amo $A$ gene (Rotthauwe et al. 1995). However, a previous ecology study compared the amo $A$ approach to the more traditional $16 \mathrm{~S}$ rRNA approach and showed a similar (though not completely identical) evolutionary relationship of AOBs based on these two methods (Purkhold et al. 2000). A recent study demonstrated even a more superior resolution of $16 \mathrm{~S}$ rRNA vs amo $A$ analysis, partly because the amo $A$ region is highly conserved (Purkhold et al. 2003). It is also reported that amo $A$-based assays may miss more AOB populations than the $16 \mathrm{~S}$ rRNA-based assays (Layton et al. 2005). Moreover, the resolution of the phylogeny based on $16 \mathrm{~S}$ rDNA sequences within the Nitrosomonas genus is reported to be relatively good (Aakra et al. 2001). Hence, because all AOBs found in this study are nitrosomonads, the amo $A$ approach would not have contributed more information to our results than was obtained with the use of the $16 \mathrm{~S}$ rRNA CTO primers.

Moving window analysis is a useful technique to follow up the stability or the rate of change in time of microbial communities (Possemiers et al. 2004). Figure 4(a,b) demonstrated that although the bacterial communities of both WWTPs studied follow almost the same course, this is not the case for the AOB subgroup. At the AOB level, it was also noticed that WWTP B showed more instability throughout the complete monitoring period than WWTP A. Moreover, a restabilization (after the disturbance at day 64) of the total bacterial community was reached by the end of the measuring period (Fig. 4a), although stabilization was not reached for the AOB subgroup that kept on fluctuating (Fig. 4b). Shifts have been reported to be related to a change in functional performance of bacterial communities. Boon et al. (2003) showed that a temporarily malfunctioning of the nitrification process can result in the consecutive upcoming and disappearance of certain species. Because changes in RNA are known to be more rapid and to precede changes in DNA by a few days, a direct comparison between the DNA and RNA analyses could only have been made if the RNA was sampled more frequently (Boon et al. 2003; Vervaeren et al. 2005). Both the cluster and moving window analysis clearly showed the usefulness of investigating bacterial subgroups and might indicate that the AOBs could be a helpful indicator subgroup for studying WWTP perturbations. Further studying along this way could lead to a precise image of which AOBs are more resistant to 
environmental disturbances. This could eventually permit fine-tuning operational WWTP parameters to benefit the presence, survival and growth of these AOB species.

As previously reported, it is important to verify for nonspecificity when using CTO primers (Purkhold et al. 2000; Cébron et al. 2004). For this purpose and simultaneously to identify the key ammonia-oxidizing bacteria in the two WWTPs, sequence analysis of the most dominant DGGE bands was performed. It appeared that bands I and J were more closely related to $A$. serpens, a common species in WWTPs (Kawai et al. 2004), than to nonspecific bands already found before when using CTO primers (Cébron et al. 2004). The other bands showed high similarity with Nitrosomonas spp. The fact that in the two WWTPs only Nitrosomonas spp. were found - although CTO primers also amplify other AOBs such as Nitrosococcus spp. and Nitrosospira (Purkhold et al. 2003) - corresponds with a previous study that only detected nitrosomonads in all but two of the 11 WWTPs analysed (Purkhold et al. 2000) and with a recent study (Layton et al. 2005). However, this is not a general finding as Nitrosococcus mobilis-like bacteria have also been reported as the dominant $\mathrm{AOB}$ species in activated sludge (Juretschko et al. 1998; Koops and PommereningRoser 2001).

In this study, it was shown that two wastewater treatment plants treating the same influent had clearly distinctive communities, in terms of total and ammoniaoxidizing bacteria. When studying these bacterial communities, it was demonstrated that certain species, which did not seem to be numerically very abundant, may be very active according to the RNA signal. Hence, when studying the activity and performance of a WWTP, a rRNA evaluation is advisable, especially when focussing on bacterial subgroups (in this case the AOBs). This research therefore demonstrates the usefulness of monitoring the performance of the nitritation process by a combination of the study of both nitritational parameters and molecular fingerprinting of the AOB community. Moreover, clustering and - especially - moving window analysis are shown to be valuable tools for monitoring community shifts in WWTPs.

\section{ACKNOWLEDGEMENTS}

This work was supported by the G.O.A. project grant (2003-2008) of the 'Ministerie van de Vlaamse Gemeenschap, Bestuur Wetenschappelijk Onderzoek' (Belgium) and the research was also funded by a $\mathrm{PhD}$ grant (nr. 41428) of the Institute for the Promotion of Innovation through Science and Technology in Flanders (IWT-Vlaanderen). The authors would like to thank Katrien Crul for technical assistance and Kristof Verthé, Han Vervaeren and Kim Windey for the critical reading of the manuscript. We also thank the pharmaceutical production company for their cooperation in sampling the activated sludge.

\section{REFERENCES}

Aakra, A., Utaker, J.B., Pommerening-Roser, A., Koops, H.P. and Nes, I.F. (2001) Detailed phylogeny of ammonia-oxidizing bacteria determined by rDNA sequences and DNA homology values. Int $\mathcal{F}$ Syst Evol Microbiol 51, 2021-2030.

Amann, R., Ludwig, W. and Schleifer, K.H. (1995) Phylogenetic identification and in situ detection of individual microbial cells without cultivation. Microbiol Rev 59, 143-169.

Amann, R., Lemmer, H. and Wagner, M. (1998) Monitoring the community structure of wastewater treatment plants: a comparison of old and new techniques. FEMS Microbiol Ecol 25, 205-215.

Blackall, L.L., Burrell, P.C., Gwilliam, H., Bradford, D., Bond, P.L. and Hugenholtz, P. (1998) The use of 16S rDNA clone libraries to describe the microbial diversity of activated sludge communities. Water Sci Technol 37, 451-454.

Boon, N., Goris, J., De Vos, P., Verstraete, W. and Top, E.M. (2000) Bioaugmentation of activated sludge by an indigenous 3-chloroaniline-degrading Comamonas testosteroni strain, I2gfp. Appl Environ Microbiol 66, 2906-2913.

Boon, N., De Windt, W., Verstraete, W. and Top, E.M. (2002) Evaluation of nested PCR-DGGE (denaturing gradient gel electrophoresis) with group-specific 16S rRNA primers for the analysis of bacterial communities from different wastewater treatment plants. FEMS Microbiol Ecol 39, 101-112.

Boon, N., Top, E.M., Verstraete, W. and Siciliano, S.D. (2003) Bioaugmentation as a tool to protect the structure and function of an activated-sludge microbial community against a 3-chloroaniline shock load. Appl Environ Microbiol 69, 1511-1520.

Cébron, A., Coci, M., Garnier, J. and Laanbroek, H.J. (2004) Denaturing gradient gel electrophoretic analysis of ammoniaoxidizing bacterial community structure in the lower Seine river: impact of Paris wastewater effluents. Appl Environ Microbiol 70, 6726-6737.

Das, P.C., Ayyappan, S., Jena, J.K. and Das, B.K. (2004) Effect of sublethal nitrite on selected haematological parameters in fingerling Catla catla (Hamilton). Aquac Res 35, 874-880.

Focht, D.D. and Verstraete, W. (1977) Biochemical ecology of nitrification and denitrification. Adv Microb Ecol 1, 135-214.

Greenberg, A.E., Clesceri, L.S. and Eaton, A.D. (1992) Standard Methods for the Examination of Water and Wastemater. Washington, DC: American Public Health Association, American Water Works Association, and Water Environment Federation.

Head, I.M., Saunders, J.R. and Pickup, R.W. (1998) Microbial evolution, diversity, and ecology: a decade of ribosomal RNA analysis of uncultivated microorganisms. Microb Ecol 35, 1-21.

Huertas, M., Gisbert, E., Rodriguez, A., Cardona, L., Williot, P. and Castello-Orvay, F. (2002) Acute exposure of Siberian sturgeon (Acipenser baeri, Brandt) yearlings to nitrite: median-lethal concentration $\left(\mathrm{LC}_{50}\right)$ determination, haematological changes and nitrite accumulation in selected tissues. Aquat Toxicol 57, 257-266.

Jensen, F.B. (2003) Nitrite disrupts multiple physiological functions in aquatic animals. Comp Biochem Physiol A Mol Integr Physiol 135, $9-24$. 
Juretschko, S., Timmermann, G., Schmid, M., Schleifer, K.H., Pommerening-Roser, A., Koops, H.P. and Wagner, M. (1998) Combined molecular and conventional analyses of nitrifying bacterium diversity in activated sludge: Nitrosococcus mobilis and Nitrospira-like bacteria as dominant populations. Appl Environ Microbiol 64, 3042-3051.

Kawai, M., Yamagishi, J., Yamaguchi, N., Tani, K. and Nasu, M. (2004) Bacterial population dynamics and community structure in a pharmaceutical manufacturing water supply system determined by real-time PCR and PCR-denaturing gradient gel electrophoresis. f Appl Microbiol 97, 1123-1131.

Keener, W.K. and Arp, D.J. (1993) Kinetic-studies of ammonia monooxygenase inhibition in Nitrosomonas europaea by hydrocarbons and halogenated hydrocarbons in an optimized whole-cell assay. Appl Environ Microbiol 59, 2501-2510.

Keener, W.K. and Arp, D.J. (1994) Transformations of aromatic compounds by Nitrosomonas europaea. Appl Environ Microbiol 60, 1914-1920.

Koops, H.P. and Pommerening-Roser, A. (2001) Distribution and ecophysiology of the nitrifying bacteria emphasizing cultured species. FEMS Microbiol Ecol 37, 1-9.

Kowalchuk, G.A. and Stephen, J.R. (2001) Ammonia-oxidizing bacteria: a model for molecular microbial ecology. Annu Rev Microbiol 55, 485-529.

Kowalchuk, G.A., Stephen, J.R., De Boer, W., Prosser, J.I., Embley, T.M. and Woldendorp, J.W. (1997) Analysis of ammonia-oxidizing bacteria of the $\beta$ subdivision of the class Proteobacteria in coastal sand dunes by denaturing gradient gel electrophoresis and sequencing of PCR-amplified 16S ribosomal DNA fragments. Appl Environ Microbiol 63, 1489-1497.

Layton, A.C., Dionisi, H., Kuo, H.-W., Robinson, K.G., Garrett, V.M., Meyers, A. and Sayler, G.S. (2005) Emergence of competitive dominant ammonia-oxidizing bacterial populations in a full-scale industrial wastewater treatment plant. Appl Environ Microbiol 71, $1105-1108$.

Limpiyakorn, T., Shinohara, Y., Kurisu, F. and Yagi, O. (2004) Distribution of ammonia-oxidizing bacteria in sewage activated sludge: analysis based on 16S rDNA sequence. Water Sci Technol 50, 9-14.

Liu, W.T., Marsh, T.L. and Forney, L.J. (1998) Determination of the microbial diversity of anaerobic-aerobic activated sludge by a novel molecular biological technique. Water Sci Technol 37, 417-422.

McCarty, G.W. (1999) Modes of action of nitrification inhibitors. Biol Fertil Soils 29, 1-9.

Muyzer, G., Dewaal, E.C. and Uitterlinden, A.G. (1993) Profiling of complex microbial populations by denaturing gradient gel electrophoresis analysis of polymerase chain reaction-amplified genes coding for 16S rRNA. Appl Environ Microbiol 59, 695-700.

Myers, R.M., Fischer, S.G., Lerman, L.S. and Maniatis, T. (1985) Nearly all single base substitutions in DNA fragments joined to a GC-clamp can be detected by denaturing gradient gel electrophoresis. Nucleic Acids Res 13, 3131-3145.

Ogram, A. (2000) Soil molecular microbial ecology at age 20: methodological challenges for the future. Soil Biol Biochem 32, $1499-1504$.

Øvreås, L., Forney, L., Daae, F.L. and Torsvik, V. (1997) Distribution of bacterioplankton in meromictic Lake Saelenvannet, as determined by denaturing gradient gel electrophoresis of PCR-amplified gene fragments coding for 16S rRNA. Appl Environ Microbiol 63, 33673373.

Philips, S., Laanbroek, H.J. and Verstraete, W. (2002) Origin, causes and effects of increased nitrite concentrations in aquatic environments. Rev Environ Sci Biotechnol 1, 115-141.

Possemiers, S., Verthe, K., Uyttendaele, S. and Verstraete, W. (2004) PCR-DGGE-based quantification of stability of the microbial community in a simulator of the human intestinal microbial ecosystem. FEMS Microbiol Ecol 49, 495-507.

Poulsen, L.K., Ballard, G. and Stahl, D.A. (1993) Use of ribosomal RNA fluorescence in situ hybridization for measuring the activity of single cells in young and established biofilms. Appl Environ Microbiol 59, 1354-1360.

Purkhold, U., Pommerening-Roser, A., Juretschko, S., Schmid, M.C., Koops, H.P. and Wagner, M. (2000) Phylogeny of all recognized species of ammonia oxidizers based on comparative $16 \mathrm{~S}$ rRNA and amo $A$ sequence analysis: implications for molecular diversity surveys. Appl Environ Microbiol 66, 5368-5382.

Purkhold, U., Wagner, M., Timmermann, G., Pommerening-Roser, A. and Koops, H.P. (2003) 16S rRNA and amoA-based phylogeny of 12 novel beta proteobacterial ammonia-oxidizing isolates: extension of the dataset and proposal of a new lineage within the nitrosomonads. Int 7 Syst Evol Microbiol 53, 1485-1494.

Rasche, M.E., Hyman, M.R. and Arp, D.J. (1990) Biodegradation of halogenated hydrocarbon fumigants by nitrifying bacteria. Appl Environ Microbiol 56, 2568-2571.

Rotthauwe, J.H., De Boer, W. and Liesack, W. (1995) Comparative analysis of gene sequences encoding ammonia monooxygenase of Nitrosospira sp. AHB1 and Nitrosolobus multiformis C-71. FEMS Microbiol Lett 133, 131-135.

Seghers, D., Top, E.M., Reheul, D., Bulcke, R., Boeckx, P., Verstraete, W. and Siciliano, S.D. (2003) Long-term effects of mineral versus organic fertilizers on activity and structure of the methanotrophic community in agricultural soils. Environ Microbiol 5, 867-877.

Seghers, D., Wittebolle, L., Top, E.M., Verstraete, W. and Siciliano, S.D. (2004) Impact of agricultural practices on the Zea mays L. endophytic community. Appl Environ Microbiol 70, 1475-1482.

Teske, A., Wawer, C., Muyzer, G. and Ramsing, N.B. (1996) Distribution of sulfate-reducing bacteria in a stratified fjord (Mariager fjord, Denmark) as evaluated by most-probable-number counts and denaturing gradient gel electrophoresis of PCR-amplified ribosomal DNA fragments. Appl Environ Microbiol 62, 1405-1415.

Torsvik, V., Daae, F.L., Sandaa, R.A. and Ovreas, L. (1998) Novel techniques for analysing microbial diversity in natural and perturbed environments. 7 Biotechnol 64, 53-62.

Vedel, N.E., Korsgaard, B. and Jensen, F.B. (1998) Isolated and combined exposure to ammonia and nitrite in rainbow trout (Oncorhynchus mykiss): effects on electrolyte status, blood respiratory properties and brain glutamine/glutamate concentrations. Aquat Toxicol 41, 325-342.

Vervaeren, H., De Wilde, K., Matthys, J., Boon, N., Raskin, L. and Verstraete, W. (2005) Quantification of an Eikelboom type 021N bulking event with fluorescence in situ hybridization and real time PCR. Appl Microbiol Biotechnol (in press). doi: 10.1007/s00253-0051963-9. 
Wagner, M., Amann, R., Lemmer, H. and Schleifer, K.H. (1993) Probing activated sludge with oligonucleotides specific for Proteobacteria: inadequacy of culture-dependent methods for describing microbial community structure. Appl Environ Microbiol 59, 1520 1525 .
Zarda, B., Hahn, D., Chatzinotas, A., Schonhuber, W., Neef, A., Amann, R.I. and Zeyer, J. (1997) Analysis of bacterial community structure in bulk soil by in situ hybridization. Arch Microbiol 168, 185-192. 